\title{
EXPLORING KEY FACTORS THAT INFLUENCE CONSUMER TRUST IN AIRLINE WEBSITES
}

\author{
Hamida Abd El Samie Mohamed \\ Associate Professor \\ Tourism Studies Department \\ Faculty of Tourism and Hotels \\ University of Sadat City \\ E-mail Address: hamidaelsayed@yahoo.com \\ Postal Address: 6 El Daher Street- Ramsis-Cairo-Egypt \\ Postal Code: 11271 \\ Mobile:00201009647811
}

\author{
Mahmoud Rammadan Al-Azab \\ Lecturer \\ Tourism Studies Department \\ Faculty of Tourism and Hotels \\ University of Sadat City \\ E-mail Address: m_ramadan1983@yahoo.com \\ Postal Address: Quesna- Menofia -Egypt \\ Postal Code: 32631 \\ Mobile:00201116545985
}

\begin{abstract}
This study is an attempt to identify the most crucial factors that enhance the level of consumer trust in airline websites. Based on a review of selected previous studies, we propose four factors that can influence consumer trust in airline websites; website quality and its dimensions (information quality, design quality, perceived ease of use and perceived usefulness), company reputation, perceive institution assurance and its dimensions (perceived security and perceived privacy), and word of mouth and recommendations. Data was collected through online self- administered questionnaire distributed through convenient sampling method. Pearson correlation and regression analysis were utilized to test the hypothesized variables. The findings revealed a positive relationship between aforementioned factors and consumer trust in airline websites. Consumer trust also influences purchase intentions. Suggestions are also given for managers in airline companies to improve the level of trust at their websites.
\end{abstract}

Keywords: consumer trust, airline websites, website quality, website design, company reputation, word of mouth and recommendations, intention to purchase, e-ticketing.

\section{Introduction}

Several studies have confirmed that trust has a crucial role in creating satisfied and expected outcomes in online transactions (Pavlou, 2003; Flavian and Guinaliu, 2006). Customer trust can be defined as a group of beliefs held by an online consumer regarding both; current characteristics of the e-supplier and his possible behavior in the future (Coulter and Coulter, 2002). Building consumer trust is a strategic necessity for most web-based vendors because trust strongly affects consumer purchase intentions especially with unfamiliar online vendors (McKnight et al., 2002). Online trust is a key indicator that determines the success or failure of e- businesses (Karimov et al., 2011). Moreover, trust can assure a high level of company performance and profitability (Palvia, 2009). Although the number of Internet users has dramatically increased, many users do not perform complete online purchases (Ponte et al., 2015). They hesitate to provide personal information for electronic payments online because they lack trust in most websites (Kim et al., 2008; Kim et al., 2011).The tourism industry has special characteristics that best suit the Internet: (1) the tourism product is intangible; (2) production and consumption are inseparable; and (3) tourism demand is perishable and varies significantly (McCole, 2002). E-commerce firstly appeared between the airline companies and the customers at the spreading of frequent flying programs (FFPs) in the mid-1980s (Kim et al., 2009). During the mid of 1990s , airline companies increasingly introduced ecommerce in order to reduce distribution costs as well as decrease the ratio of fixed costs in the price structure (Kim et al., 2009). Besides, airline companies directed their businesses via the internet to achieve a long-term competitive advantage, global competitiveness, customer satisfaction, and to enhance marketing efficacy and managerial efficiency (Tsai et al., 2005; Ho and Lee, 2007; Lubbe, 2007). Electronic ticketing has radically changed the airline industry and behavior of consumers, besides reducing cost and providing new channel for communication (Sam and Tahir, 2009). The benefits of 
Internet use in the purchase of e-tickets are fundamental in order to know customers better (Akehurst, 2009) and to reduce the distribution costs of the airlines industry (Chen, 2007) and to increase market share through the improvement of online performance and satisfaction with the website (Harison and Boonstra, 2008). Kim et al. (2008) observed that customers' intention to purchase products online was affected by trust in the web merchant. For this reason, online merchants should continuously improve website quality and update website services to enhance buyers' trust (Hsiao et al., 2010). Airline companies need to identify procedures that lead to the satisfaction, trust and loyalty of users to their websites (Ruiz et al., 2009).

The present study addresses the following questions;

What is consumer trust in the e-business domain?

What are the key drivers that influence consumer trust in airline websites?

What are the interrelated relationships among the suggested factors of trust?

What is the relationship between trust and consumers' purchase intentions in airline websites?

\section{Literature Review}

\section{Defining trust}

Consumers' trust in e-commerce represents an important factor of the word of mouth for the newcomers (Mazhar et al., 2012). Trust has been defined as "a willingness to rely on an exchange partner in whom one has confidence" (Moorman et al., 1993: 315); and "a belief in a person's competence to perform a specific task under specific circumstances" (Sitkin and Roth, 1993: 373). McKnight and Chervany (2001) defined trust as an individual's belief regarding various attributes of the other party involved in an ecommerce relationship and could be measured through the standards of fairness, goodness, strength, ability, benevolence, honesty and predictability. Credibility and benevolence have been proposed as the fundamental dimensions of trust (Ganesan, 1994; Doney and Cannon, 1997). Actually, a website presents affective, cognitive and institutional signals that shape a consumer's first impressions about the webvendor (Hu et al., 2010; Lee and Huh, 2011). Affect-based trust is defined as the extent to which one feels secure and comfortable about depending upon the trustee (Komiak and Benbasat, 2004). Cognition-based trust is defined as a consumer's rational expectation that an online vendor has the necessary attributes to be reliable (Komiak and Benbasat, 2004). Institution-based trust is enhanced when customers feel comfortable because of the presence of guarantees on the website (Bahmanziari et al., 2009). Online trust can be defined as an attitude of confident expectation in an online situation of risk that one's vulnerabilities will not be developed (Corritore et al., 2003). E-trust can be defined as a consumer's confidence and belief regarding the behavior intention of an online seller, who must react on equal footing with the e-shopper's interests, be honest in the transactions and deliver the services requested (Kim et al. 2009). In e-commerce, a trusting consumer usually intends to: (1) make future purchase(s) from the website; (2) make current purchase(s) from the website; (3) return to visit and purchase from the same website; (4) follow advice given by that website; (5) share his/her information with the e-vendor; and (6) recommend this website to other people (Koufaris \& Hampton-Sosa, 2002; McKnight et al. , 2002; Sultan et al., 2002). According to Shankar et al. (2002), consequences of online trust can be grouped into three broad categories: (1) intent to act, (2) stakeholder satisfaction and loyalty, and (3) firm performance.

\section{Drivers of trust in airline websites}

Airlines are increasingly directing their businesses to the web for specific reasons such as; the provision of electronic tickets, transparent and clear pricing, financial incentives for self-booking online, online promotions, powerful customer relationship management systems and online advertising strategies (Yu, 2008). The purchase of the ticket on the company's website by the passenger is motivated by convenience factors such as 24/7 accessibility, or the speed of access to much up-to-date information (Gil et al., 2006), ease of use or the quality of information being dimensions of the quality of service in the online environment (Forgas et al. 2012). Palmer (2002) indicates that website success is significantly related with website download delay, navigation, information, interactivity and responsiveness. Guo and Salvendy (2009) examined the significant content factors of e-business websites. The results of their study 
indicated that these factors are security content, quality content, service content, appearance description, contact information, aid function, customized function, search function and product. Hernandez et al. (2009) analyzed the main factors that should be considered when designing a commercial website. Their results determined that the information provided on the website must be accurate, informative, up-to-date and relevant to the customers' requirements. Luna-Nevarez and Hyman (2012) studied the content of websites for top global destinations. They investigated six factors: navigation and interactivity, visual and presentation style, textual information, use of social media, use of advertising. Sultan et al. (2002) found that customer perceptions of trust are determined by Web site and consumer characteristics. Nine Web-site factors, namely, navigation, advice, no errors, fulfillment, community, privacy/security, trust seals, brand and presentation drive trust (Sultan et al., 2002). There are four categories of antecedents that influence consumer trust and consumers' perceived risk towards e-businesses (Barney \& Hansen, 1994; Doney \& Cannon, 1997; Mcknight et al., 2002):

- Cognition-based: e.g., privacy protection, security protection, system reliability, information quality, etc.

-Affect-based: e.g., reputation, presence of third-party seals, referral, recommendation, buyers' feedback, word-of-mouth, etc.

- Experience-based: e.g., familiarity, Internet experience, e-commerce experience, etc.

- Personality-oriented: e.g., disposition to trust, shopping style, etc. In this research, four factors are tested as being the key drivers that can affect the level of trust in airline websites, which are related to consumer perceptions, such as; website quality, company reputation, perceived institution assurance and word of mouth. As shown in figure (1) a comprehensive framework is proposed to explore the key factors influencing consumer trust in airline websites.

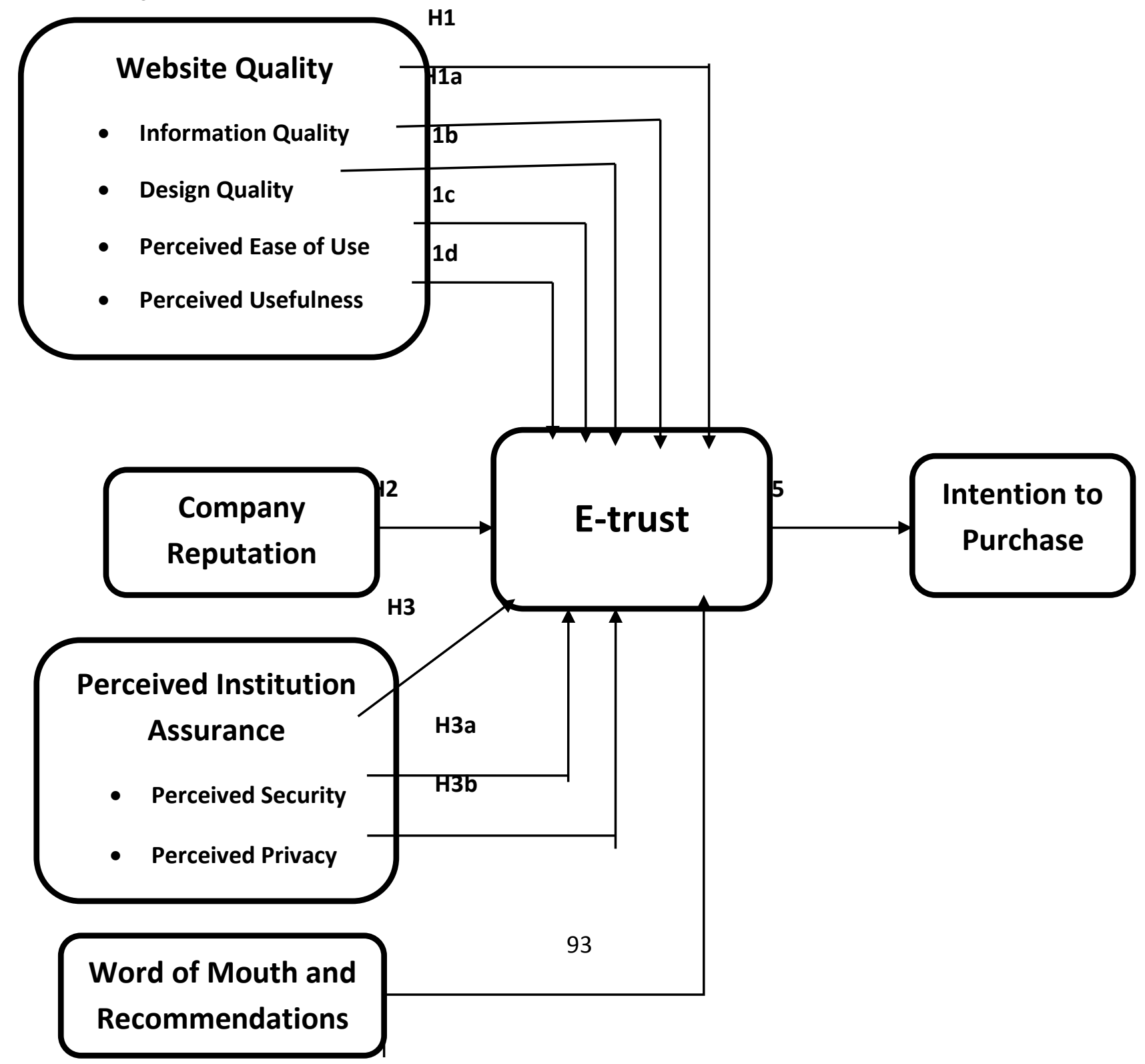


Figure 1 Conceptual framework of the research hypotheses

\section{Website Quality}

Nowadays, customers are smarter and more demanding; they evaluate the quality of internet technology based on how they perceive the quality criteria of a particular specific website (Winnie, 2014). Website quality is a platform of information technology (Liu and Arnett, 2000) which determines the effectiveness of website (Lin, 2008). It provides an effective and efficient e-purchasing domain and delivery process of products or services to the customers (Zeithaml et al., 2002). In SERVQUAL-related studies (Lin, 2007), researchers demonstrated that service quality or web quality, which usually includes the reliability, responsiveness or empathy of a service, has a significant influence on trust.

Most of the web quality scales were developed based on the traditional service quality scale SERVQUAL (Parasuraman et al., 1985). There are also other scales that measure the website quality; SITEQUAL (Yoo and Donthu, 2001), E-SERVQUAL (Zeithaml et al., 2000) and E-S-QUAL (Parasuraman et al., 2005). Electronic service quality (E-SQ) is the most famous concept used to measure website quality. It is the extent to which a website facilitates efficient and effective shopping, purchasing, and delivery (Parasuraman et al. 2005). Website quality can be defined as the degree to which the website's features meet what user's needs (Hsiao et al., 2010; Filieri et al., 2015; Agag and El-Masry, 2016). Hsiao et al. (2010) pointed out that perceived website quality positively builds and increases consumer's trust in the website. Thus, the first hypothesis can be formulated as follows:

\section{H1: Website Quality positively influences consumer trust in airline websites.}

Lin (2010) develops several constructs relating to website quality; functional needs service, information quality, relevance of information, perceived ease of use and perceived usefulness. Moreover, previous studies have demonstrated that some of the most used key dimensions of online service quality research were navigability, playfulness, information quality, trust, personalization and responsiveness (Nusair and Kandampully, 2008), perceived ease of use, perceived usefulness, perceived social presence, trust, enjoyment (Hassanein and Head, 2007), website design, reliability, responsiveness, trust, personalization (Lee and Lin, 2005) and ease of use, information quality, website design, customer service, process controllability and outcome quality (Su et al., 2008). Regarding tourism industry, Ho and Lee (2007) develop a scale of five dimensions; information quality, security, functionality, customer relationship and responsiveness. Of the many dimensions proposed in the academic literature on the website quality, this study considered four dimensions for measuring the quality of airline websites, namely; information quality, website design, perceived ease of use and perceived usefulness.

Information quality Product/service information quality is defined as the customer perception of the quality of information about the product/service that appears on a specific website (Park and Kim, 2003). The information quality of a website is a significant aspect for website effectiveness (Rahimnia and Hassanzadeh, 2013). Information quality refers to the amount, accuracy and the form of information about the products and services offered on a website (Nusair and Kandampully, 2008). The important and up-to-date information also affect online consumers to make smarter purchasing decision (Surjadjaja et al., 2003). Customers expect that any website should be free from errors (Bart et al., 2005). They are also likely to trust websites that contain accurate, current, and complete information (Kim et al., 2005) and those that respect the rules of correct spelling, grammar, and syntax (Koehn, 2003). Information quality is found to be a significant predicator of online trust, customer satisfaction, and loyalty (Fung and Lee. 1999; Liao et al., 2006; Cyr, 2008; Kim et al., 2004; 2008). Accordingly, information quality provided by the B2C websites can greatly influence consumers' purchase intentions (Eid, 2011). Then, depending on the website's information quality, consumers can determine whether the site is suitable or not suitable for their needs and whether the seller is trustworthy or not (Ponte et al., 2015) and help them to reduce the levels of uncertainty associated with e-commerce transaction (Kim et al.,2008). Hence, it is hypothesized that:H1a: Information Quality positively influences consumer trust in airline websites. 
Website design A great website design must own good accessibility (e.g., timing, loading speed and the quality of internet line) and good quality of website support system (Liang and Lai, 2002). Website design is a critical part of internet marketing strategy and an important factor in building trust (Shankar et al. 2002; Urban et al., 2000). Web design features can be grouped into three broad categories (Karimov et al., 2011); (1) visual design, (2) social cue design, and (3) content design. Visual design is defined as graphical and structural factors that give consumers a first impression (Karimov et al., 2011). Social cue design comprises social cues such as face-to-face interaction and social presence, fixed into the web interface via different communication media (Karimov et al., 2011). Tan et al. (2009) find that webdesigners perceive elements belonging to visual design such as "Color usage", "Layout/Space usage", "Graphics usage" and "Presentation of information" as the most effective attributes of B2C websites. Content design refers to the information components of a website, either textual or graphical (Wang and Emurian, 2005). These components can be: company information (i.e., contacts, company background, FAQ), comprehensive product information (i.e., descriptions, price information), service information (i.e., delivery and return policies), and privacy policies (Chang and Chen, 2008). Moreover, Robbins and Stylianou (2003) classify the design dimension into three factors: search function, protected content and presentation content.

Law and Leung (2000) suggested that the basic attributes of successful airlines websites;

1- Product information, pricing and online ordering information;

2- Extra benefits, such as discounted airfares and free upgrades for online customers;

3- Fast loading web pages, especially home page;

4- Additional services and facilities to attract customers and cultivate customer loyalty.

Corritore et al. (2005) found out that a web design of the best quality is an ideal way to induce trustworthiness for users. Good design enables customers to use the website content and features such as text, sound, search bar, pictures, graphics and to browse the website quickly and easily (Sam \& Tahir, 2009).Based on the forgoing views, , it is hypothesized that:

H1b: Design Quality positively influences consumer trust in airline websites.

Perceived ease of use and perceived usefulness Customers evaluate the usefulness and ease of use of a particular website, according to information search, internet subscription and payment methods (Grace and Chia, 2009).Davis (1989, p. 320) defined perceived ease of use as "the degree to which a person believes that the use of a particular system would be free of effort" whereas perceived usefulness is defined as "the degree to which a person believes that the use of a particular system would enhance his or her job performance." Perceived ease of use in the context of electronic services focuses on the navigational structure of the website, which includes search functions, site maps, product indices, and the overall design and organization of the websites (Lohse and Spiller, 1998). Navigation and presentation refer to the appearance, layout, and possible sequence of clicks, images, and paths on a Web site (Bart et al., 2005). Factors such as navigation and presentation, convenience, and ease of use lead to trustworthiness (Belanger et al., 2002). The speed of navigation is also important to the success of website design (Osman et al., 2010). Taylor and England (2006) stated that the concept of navigation can include: (1) navigation bars - navigation text, images, or animations; (2) individual hyperlinks - connecting two individual web pages in a website; (3) image maps - containing a number of hyperlinks; (4) drop down menus/collapsible menus - where all choices are not permanently visible; and (5) search options locating content in the whole website or sections of the website. The impact of perceived ease of use on the formation of trust in e-commerce has been supported in several studies (Koufaris and Hampton-Sosa, 2004; Bart et al., 2005; Chen, 2006; Flavian et al., 2006). Navigation can positively influence online consumers' purchasing intentions (Verhagen and Van Dolen, 2009).Therefore, it is hypothesized that:

\section{H1c: Perceived ease of use positively influences consumer trust in airline websites.}

In this study, perceived usefulness refers to the extent to which the consumers believe that buying e-tickets through airline websites will bring him many benefits such as saving time and money and increase their trust in the website. This leads to the hypothesis that H1d: Perceived usefulness positively influences consumer trust in airline websites. 
Company Reputation Reputation can be a key element for building trust for a long time for web vendors especially in the initial trust phase (Fung and Lee, 1999; McKnight et al., 2002). The reputation (social influences/subjective norms) of the parent companies can provide a cue for the evaluation of the reliability value of the websites (Jarvenpaa et al., 1999). Tams (2009) concluded that web vendors' reputations had a significant influence on consumers' trust. Company reputation can be considered as an important factor for reducing risk and creating trust (Kim et al., 2008). Positive reputation of airline company significantly influences consumers' trust and vice versa (Chen, 2006; Hsiao et al., 2010; Agag and El-Masry, 2016). Against that background, the study proposes the following hypothesis:

H2: Company reputation positively influences consumer trust in airline websites.

Institutional structural assurances (Perceived security and perceived privacy) Structural assurance means that the web has protective legal or technological structures (Borenstein, 1996) to guarantee the aspects of safety security concerns on that website. Structural assurances on the web can also prevent consumers from losing their personal data (McKnight et al., 2004). Shapiro (1987) defined structural assurances as structural safeguards such as regulations, guarantees, and legal recourse. Perceived institutional assurance can enhance consumers' trust in a website (McKnight et al., 1998). Security and privacy elements are key drivers of online trust (Hoffman et al., 1999). A study of e-commerce showed that more than $87 \%$ of users were concerned about security and privacy protection in online shopping (Ray et al., 2011). Another important aspect that affects online ticketing usage in airline industry is security (Kiong et al., 2014). Security is the website ability to protect consumer's personal information (Xiaoying et al., 2012). Kolsaker and Payne (2002) mentioned that security concerns reflect perceptions regarding the reliability of the payment methods used and the mechanisms of data transmission and storage. Transaction security aspects significantly influence online trust (Yoon, 2002). Flavian and Guinalýu (2006) demonstrated that trust in the internet is particularly influenced by the security perceived by consumers.

Privacy refers to the protection of individually identifiable information on the internet, and it involves the adoption and implementation of a privacy policy, notice, disclosure on the website (Bart et al., 2005). The inclusion of seals of approval or third-party certificates into the content design has been widely accepted as an important strategy to assure consumers that the web sites are trustworthy (Wang and Emurian, 2005). These assurance symbols can be whether in the form of a logo or statement, such as BBB On-Line, TRUSTe, and VeriSign (Wang and Emurian, 2005). Hu et al. (2001) classified the trusted seals into five types based on their functionality, namely protecting privacy, providing security, demonstrating consumer satisfaction, providing reliability, and providing assurance or guarantee. Lauer and Deng (2007) assure the introduction of stronger privacy policies in a company's website leads to higher perception of the company's trustworthiness. Most of the customers are willing to purchase e-tickets not only for convenience reason but also for the security of the payment process (Kiong et al., 2014). E-ticketing allows consumer to enter information directly into the airline's company database (Kiong et al., 2014). Consumers expect websites that protects personal data, provide for secure payment, and sustain the privacy of online transactions (Franzak et al., 2001).

Flavian and Guinalýu (2006) demonstrated that trust in the internet is particularly influenced by the privacy perceived by consumers regarding the protection of their private data. The consumers' perception of security/privacy protection increases the consumers' trust towards the website (Kim et al., 2008; Alam and Yasin, 2010). Based on prior research, it is hypothesized that:

H3: High level of institution assurance positively influences consumer trust in airline websites.

H3a: High level of perceived security protection positively influences consumer trust in airline websites.

H3b: High level of perceived privacy protection positively influences consumer trust in airline websites.

Word of Mouth and Recommendations Word of Mouth can be considered as an important form of marketing communications forms which effectively influence consumers' perceptions, attitudes and 
behavior (Alam and Yasin, 2010; Ladhari and Michaud, 2015). Filieri et al. (2015) argued that, consumers who depend on friend's recommendations are more likely to make their decision. While negative WOM and recommendations decreases the probability of purchase; positive WOM and recommendations creates the opposite effect (Ladhari and Michaud, 2015).This study assumes that positive WOM and recommendations about a website, increase consumer's trust. This leads to the following hypothesis:

\section{H4: Positive Word of Mouth and recommendations positively influences consumer's trust in airline websites}

\section{Trust and Purchase Intention}

Purchase intention is defined as" the probability that the consumer will purchase the product" (Sam and Tahir, 2009:4). Intent is itself affected by attitudes toward the behavior, subjective norms about involving in the behavior, and perceptions about whether the individual will be able to successfully engage in the target behavior (George, 2004). Lee and Lin (2005) suggested that trust encourages online purchasing intentions of consumers. Higher level of trust to an online store is more likely to bring more intention of purchase (Öztüren, 2013). Several studies have confirmed the relationship between trust and the intention to purchase online (Jarvenpaa et al., 2000; Yoon, 2002; Chang and Chen, 2008; Cyr et al., 2008; Kim et al., 2008; Chiu et al., 2010, Kim et al., 2012). In the field of tourism and e-commerce, this relationship has also been examined and the results assured that the influence is significant and positive (Bigne, 2010; Kim et al., 2009, 2011; Escobar-Rodríguez and Carvajal-Trujillo, 2014).Hsiao et al. (2010) noted that there are a positive relationship between consumers' trust in a website and their purchase intentions. Hence, it is hypothesized that:

H5: Consumer Trust in airline website positively influences consumer intention to purchase e-tickets from this website.

\section{Methodology}

An empirical study was designed to test the research framework and the abovementioned hypotheses. The target respondents of the study include all consumers who buy airline tickets online. The respondents were asked whether they had experience in online purchasing before completing the questionnaire, as only persons who have experienced online purchasing from airline websites could participate in this study. The respondents were asked about the frequency they purchased online tickets and to mention the name of Airline Company where they have made online transactions. The airline companies are chosen because they are one of the most effective and competitive industries applying electronic transactions in their business in the world. The questionnaire was available online between January 10 and April 15, 2017. Data were collected using an online survey. (182) copies of the questionnaire were distributed to the selected sample. Only 166 respondents agreed to complete the survey with a response rate of $(91.2 \%) ; 16$ copies $(8.8 \%)$ were excluded.

\section{Measures}

The questionnaire consists of seven sections: demographic characteristics, website quality (includes information quality, design quality, perceived ease of use, perceived usefulness), e-trust, company reputation, perceived institution assurance (includes perceived security protection and perceived privacy protection), word of mouth and recommendation and intention to purchase. The research instrument includes 56 items. The measurement of website quality items were adapted from Rahimnia and Hassanzadeh (2013); Corfu et al., (2003); Guo, and Salvendy, (2009); Detlor et al. (2003); Kim et al., (2008); RuelNova-bos et al.(2015); Chen (2006); Filieri et al., (2015); and Agag \& El-Masry (2016). The measurement of e-trust items was based on studies conducted by Rahimnia and Hassanzadeh (2013); Agag and El-Masry (2016); Filieri et al., (2015); Kim et al., (2008); Chen (2006); Hsiao et al., (2010). The measurement of company reputation items were adapted from Alam and Yasin (2010); Kim et al., (2008); and Bilgihan (2016). The measurement of perceived institution assurance dimensions were adapted from Molina et al., (2009); Chen (2006); Alam and Yasin (2010); Kim et al., (2008); and Hsiao 
et al., (2010). The measurement of Word of mouth and recommendation items were adapted from Alam and Yasin (2010); Filieri et al., (2015); and RuelNovabos et al. (2015). Finally, the measurement of purchase intention items was adapted from Agag and El-Masry (2016) and Molina et al., (2009). A 5point Likert scale is used as a measurement scale ranging from 1 (Strongly Disagree) to 5 (Strongly Agree).

\section{Data Analysis}

Table (1) presents the demographic characteristics of respondents. The sample included (28.3\%) female and $(71.1 \%)$ male respondents. The respondents' age ranged from 31 to 41 years old (47\%). In terms of education, the majority of respondents have a Bachelor's degree $(71.1 \%)$ and most of them were employees (84.3\%). The respondents have good experience to buy online tickets; $(51.2 \%)$ of them buy online tickets (1-5) times, (13.9\%) of them (6-10) times and (34.9\%) of them buying tickets online more than 11 times. The majority of the respondents (56\%) buy tickets through Egypt Air website, and (21.1\%) from Saudi Airlines, (7.8\%) from Fly Emirates and only (4.8\%) from Qatar Airways and (10.3\%) from other companies.

Table 1 Demographic Characteristics

\begin{tabular}{|c|c|c|c|c|c|}
\hline Gender & Frequency & $\%(n=166)$ & $\begin{array}{c}\text { Frequency of buying } \\
\text { online tickets }\end{array}$ & Frequency & $\%(n=166)$ \\
\hline $\begin{array}{c}\text { Male } \\
\text { Female }\end{array}$ & $\begin{array}{c}119 \\
47\end{array}$ & $\begin{array}{l}71.7 \\
28.3\end{array}$ & \multirow{3}{*}{$\begin{array}{c}1-5 \\
6-10 \\
11+\end{array}$} & \multirow{3}{*}{$\begin{array}{l}85 \\
23 \\
58\end{array}$} & \multirow{3}{*}{$\begin{array}{l}51.2 \\
13.9 \\
34.9\end{array}$} \\
\hline Age & Frequency & $\%(\mathrm{n}=166)$ & & & \\
\hline Less than 20 & \multirow{3}{*}{$\begin{array}{c}6 \\
73 \\
78 \\
9\end{array}$} & \multirow{3}{*}{$\begin{array}{c}3.6 \\
44.0 \\
47.0 \\
5.4\end{array}$} & & & \\
\hline 20-30 & & & $\begin{array}{c}\text { Frequency of internet } \\
\text { purchases }\end{array}$ & Frequency & $\%(n=166)$ \\
\hline $\begin{array}{c}31-41 \\
\text { More than } 41\end{array}$ & & & \multirow{3}{*}{$\begin{array}{c}\text { Never } \\
1-5 \\
6-10 \\
\text { More than } 11\end{array}$} & \multirow[b]{3}{*}{$\begin{array}{l}10 \\
83 \\
32 \\
41\end{array}$} & \multirow[b]{3}{*}{$\begin{array}{c}6.0 \\
50.0 \\
19.3 \\
24.7\end{array}$} \\
\hline Education & Frequency & $\%(\mathrm{n}=166)$ & & & \\
\hline $\begin{array}{c}\text { Below secondary } \\
\text { High school } \\
\text { Bachelor's degree } \\
\text { Graduate degree }\end{array}$ & $\begin{array}{c}- \\
- \\
118 \\
48\end{array}$ & $\begin{array}{c}- \\
71.1 \\
28.9\end{array}$ & & & \\
\hline Occupation & Frequency & $\%(n=166)$ & Airline Name & Frequency & $\%(n=166)$ \\
\hline $\begin{array}{c}\text { Employee } \\
\text { Self-employed } \\
\text { Students } \\
\text { Retired } \\
\text { Others }\end{array}$ & $\begin{array}{c}140 \\
4 \\
8 \\
5 \\
9\end{array}$ & $\begin{array}{c}84.3 \\
2.4 \\
4.8 \\
3.0 \\
5.4\end{array}$ & $\begin{array}{c}\text { Egypt Air } \\
\text { Saudi Airline } \\
\text { Qatar Airways } \\
\text { Fly Emirates } \\
\text { Others }\end{array}$ & $\begin{array}{c}93 \\
35 \\
8 \\
13 \\
17\end{array}$ & $\begin{array}{c}56.0 \\
21.1 \\
4.8 \\
7.8 \\
10.3\end{array}$ \\
\hline
\end{tabular}

Reliability analysis was performed to ensure internal validity and consistency of the items used for each variable. As shown in table (2), Cronbach's Alpha reliability values were all above (0.9). Accordingly, the questionnaire is a reliable measurement instrument.

Table 2 Cronbach's Alpha (Reliability)

\begin{tabular}{|c|c|c|}
\hline Variables & $\begin{array}{c}\text { Cronbach's } \\
\text { Alpha }\end{array}$ & No. of items \\
\hline 1.Website Quality & .977 & 28 \\
\hline A. Information Quality & .978 & 7 \\
\hline
\end{tabular}




\begin{tabular}{|c|c|c|}
\hline B. Design Quality & .977 & 7 \\
\hline C. Perceived Ease of Use & .979 & 7 \\
\hline D. Perceived Usefulness & .977 & 7 \\
\hline 2. E-trust & .977 & 8 \\
\hline 3. Company Reputation & .978 & 4 \\
\hline 4. Institution Assurance & .978 & 8 \\
\hline A. perceived security protection & .978 & 4 \\
\hline B. perceived privacy protection & .985 & 4 \\
\hline 5.WOM and Recommendations & .977 & 4 \\
\hline 6.Intention to Purchase & .978 & 4 \\
\hline
\end{tabular}

Table (3) demonstrates the descriptive statistics for the study variables through mean and standard deviation. As shown in table (3), intentions to purchase was the highest mean (4.35) with a standard deviation of (1.037), and the lowest mean was for perceived privacy protection (3.37) with a standard deviation of $(.961)$

Table 3 Descriptive statistics of the study variables

\begin{tabular}{|c|c|c|c|}
\hline Variables & Adopted from & Mean & Std. Deviation \\
\hline 1. Website Quality & & 4.22 & .693 \\
\hline Information Quality & & 4.26 & .733 \\
\hline $\begin{array}{l}\text { The airline website tells the customer how he/she can communicate with the company (tel., } \\
\text { Fax, E-mail ...) }\end{array}$ & \multirow{7}{*}{$\begin{array}{c}\text { Rahimnia and } \\
\text { Hassanzadeh (2013); } \\
\text { Corfu et al., (2003); } \\
\text { Guo, and Salvendy, } \\
\text { (2009); Detlor et al. } \\
\text { (2003); Kim et al., } \\
\text { (2008). }\end{array}$} & 4.33 & .717 \\
\hline $\begin{array}{l}\text { The airline website provides a detailed } \\
\text { products and services. }\end{array}$ & & 4.39 & .769 \\
\hline $\begin{array}{l}\text { The airline website provides pricing increment /decrement information about the products and } \\
\text { services. }\end{array}$ & & 4.14 & .887 \\
\hline The airline website clearly lists the restrictions of discount and sale. & & 4.02 & .944 \\
\hline $\begin{array}{l}\text { The airline website clarifies the purchase } \\
\text { customers. }\end{array}$ & & 4.04 & .930 \\
\hline The airline website provides up- to -date information. & & 4.48 & .879 \\
\hline The airline website provides reliable information. & & 4.43 & .781 \\
\hline Website Design & & 4.12 & .759 \\
\hline The airline website provides product photos from different directions. & \multirow{7}{*}{$\begin{array}{c}\text { Rahimnia and } \\
\text { Hassanzadeh (2013); } \\
\text { Detlor et al. } \\
\text { (2003); RuelNova-bos } \\
\text { et al.(2015); } \\
\text { Chen (2006); } \\
\text { Ladhari and Michaud } \\
\text { (2015). }\end{array}$} & 3.63 & 1.141 \\
\hline The airline website provides search and category function by brief information. & & 3.89 & .839 \\
\hline The airline website provides the possibility of website language change. & & 4.41 & .817 \\
\hline There should be a search bar on even web page of the airline website. & & 4.31 & .845 \\
\hline The airline website's colors were easy on the eyes. & & 4.29 & .824 \\
\hline The graphics on this website are likeable. & & 4.15 & .719 \\
\hline The airline website design is professional. & & 4.18 & .923 \\
\hline Perceived ease of use & & 4.32 & .725 \\
\hline It is easy to locate the main menu and search bar on the website. & \multirow{6}{*}{$\begin{array}{c}\text { Ruel Novabos et } \\
\text { al.(2015); Chen } \\
\text { (2006); Filieri et al., } \\
\text { (2015). }\end{array}$} & 4.40 & .746 \\
\hline It is easy to navigate this website. & & 4.27 & .956 \\
\hline It is easy to get familiar with this website. & & 4.24 & .882 \\
\hline This airline website is well-organizes hyperlinks. & & 4.07 & .871 \\
\hline This airline website uses simple language. & & 4.52 & .658 \\
\hline It is easy to find the information I am looking for (Schedules, flights). & & 4.48 & .822 \\
\hline
\end{tabular}




\begin{tabular}{|c|c|c|c|}
\hline The overall layout of this website is clear. & & 4.29 & .747 \\
\hline Perceived usefulness & & 4.19 & .665 \\
\hline Purchasing tickets from this website helps me to clear doubts when I plan a travel. & \multirow{7}{*}{$\begin{array}{l}\text { Agag and El-Masry } \\
\text { (2016); Kim et al., } \\
\text { (2008); Chen (2006). }\end{array}$} & 4.25 & .877 \\
\hline I can save time by using this airline Website. & & 4.42 & .818 \\
\hline I can save money by using this airline website. & & 4.19 & .934 \\
\hline $\begin{array}{l}\text { Using this Website enables me to accomplish a transaction more quickly than using traditional } \\
\text { sites. }\end{array}$ & & 4.22 & .671 \\
\hline This airline website has given me individual attention. & & 4.35 & .659 \\
\hline The online customer service or help on this site is available at any time. & & 3.63 & .974 \\
\hline In general, this website is useful to purchase a ticket. & & 4.27 & .772 \\
\hline 2-E-trust & & 3.95 & .714 \\
\hline This airline website is reliable. & \multirow{8}{*}{$\begin{array}{c}\text { Rahimnia and } \\
\text { Hassanzadeh (2013); } \\
\text { Agag and El-Masry } \\
\text { (2016); Filieri et al., } \\
\text { (2015); Kim et al., } \\
\text { (2008); Chen (2006); } \\
\text { Hsiao et al., (2010); } \\
\text { Molina et al., (2009). }\end{array}$} & 4.09 & 1.089 \\
\hline This airline website product is trustworthy. & & 4.13 & .891 \\
\hline This airline website has a strong sense of integrity. & & 4.12 & .769 \\
\hline the information offered by this website is sincere and honest. & & 4.22 & .758 \\
\hline I trust that this website keeps my best interests in mind. & & 4.22 & .617 \\
\hline This airline Website gives the impression that it keeps promises and commitments. & & 4.19 & .857 \\
\hline I trust in the information that this website provides. & & 3.98 & .904 \\
\hline I am not sure that trusting this site would be a good idea. & & 2.65 & 1.431 \\
\hline 3-Company Reputation & & 4.10 & .765 \\
\hline I feel very comfortable purchasing this ticket online. & \multirow{4}{*}{$\begin{array}{c}\text { Alam and Yasin } \\
\text { (2010); Kim et al., } \\
(2008) \text {; Bilgihan } \\
\text { (2016). }\end{array}$} & 4.19 & .746 \\
\hline This airline website always delivers on what they promise. & & 4.11 & .812 \\
\hline This airline website has a good reputation in the market. & & 4.11 & .870 \\
\hline $\begin{array}{l}\text { Even if another airline website has the same features as this website, I would prefer to book } \\
\text { through this website. }\end{array}$ & & 3.99 & .805 \\
\hline 4. Perceived Institution Assurance & & 3.71 & .820 \\
\hline Perceived Privacy Protection & & 3.37 & .961 \\
\hline I feel that my privacy is protected when I'm purchasing ticket online. & \multirow{4}{*}{$\begin{array}{l}\text { Chen }(2006)) \text {; Alam } \\
\text { and Yasin (2010). }\end{array}$} & 4.02 & .754 \\
\hline I feel that my personal information could be used without my permission. & & 2.78 & 1.394 \\
\hline I feel my personal data would be wrongfully used. & & 2.73 & 1.483 \\
\hline The privacy policy on this airline website is clear. & & 3.96 & .781 \\
\hline Perceived Security Protection & & 4.05 & .850 \\
\hline I trust this airline website with respect to my credit card information. & \multirow{4}{*}{$\begin{array}{c}\text { Kim et al., (2008); } \\
\text { Alam and Yasin } \\
\text { (2010); ); Hsiao et al., } \\
\text { (2010). }\end{array}$} & 3.98 & .849 \\
\hline This Website implements security measures to protect Internet shoppers. & & 4.17 & .831 \\
\hline I feel secure about the electronic payment system on this Web site. & & 4.05 & .903 \\
\hline In general, this website is a safe environment in which to buy. & & 4.00 & 1.003 \\
\hline \multicolumn{4}{|l|}{ 5. Word of Mouth and Recommendations } \\
\hline I find information given by my friends and relatives about this airline website are trustworthy. & \multirow{3}{*}{$\begin{array}{c}\text { Alam and Yasin } \\
\text { (2010); Filieri et al., } \\
\text { (2015); RuelNovabos } \\
\text { et al.(2015); }\end{array}$} & 4.11 & .725 \\
\hline $\begin{array}{l}\text { Many of my friends and relatives recommended me to purchase my airline ticket } \\
\text { online. }\end{array}$ & & 3.98 & .849 \\
\hline I recommended this airline website to close personal friends. & & 3.99 & .975 \\
\hline
\end{tabular}




\begin{tabular}{|c|c|c|c|}
\hline I am likely to share the website to my friends. & & 4.03 & .969 \\
\hline 6. Intentions to Purchase & & 4.35 & $\mathbf{1 . 0 3 7}$ \\
\hline My willingness to purchase a travel ticket from this airline website is high. & \multirow{4}{*}{$\begin{array}{l}\text { Agag and El-Masry } \\
\text { (2016); Molina et al., } \\
\text { (2009). }\end{array}$} & 4.16 & .773 \\
\hline IF I were to purchase a travel ticket, I would consider purchasing it from this website. & & 4.10 & .796 \\
\hline I intend to continue visiting this airline website in the future. & & 4.10 & .885 \\
\hline I will certainly use the Internet to buy airline tickets. & & 4.17 & .763 \\
\hline
\end{tabular}

\section{Results and Discussion}

Pearson correlations are calculated in Table (4) to examine the relationship among the study variables. The results indicated that these variables are related and supported for further analysis. Most factors are significantly related to each other, the greatest relationship is between Word of mouth and recommendations and trust (.909).

Table 4 Correlation of the study variables

\begin{tabular}{|c|c|c|c|c|c|c|c|}
\hline Variables & & 1 & 2 & 3 & 4 & 5 & 6 \\
\hline \multirow{2}{*}{ Trust } & $\begin{array}{l}\text { Pearson } \\
\text { Correlation }\end{array}$ & 1 & $.883^{\prime \prime}$ & .909 & .849 & .891 & .894 \\
\hline & $\begin{array}{ll}\begin{array}{l}\text { Sig. } \\
\text { tailed) }\end{array} & \text { (2- } \\
\end{array}$ & & .000 & .000 & .000 & .000 & .000 \\
\hline \multirow[t]{2}{*}{ Company Reputation } & $\begin{array}{l}\text { Pearson } \\
\text { Correlation }\end{array}$ & $.883^{n}$ & 1 & .846 & .839 & .782 & .899 \\
\hline & $\begin{array}{ll}\begin{array}{l}\text { Sig. } \\
\text { tailed) }\end{array} & \text { (2- } \\
\end{array}$ & .000 & & .000 & .000 & .000 & .000 \\
\hline \multirow{2}{*}{$\begin{array}{l}\text { WOM and } \\
\text { Recommendations }\end{array}$} & $\begin{array}{l}\text { Pearson } \\
\text { Correlation }\end{array}$ & $.909^{\star x}$ & $.846^{\pi *}$ & 1 & $.947^{\pi}$ & $.787^{*}$ & .897 \\
\hline & $\begin{array}{ll}\begin{array}{l}\text { Sig. } \\
\text { tailed) }\end{array} & \text { (2- } \\
\end{array}$ & .000 & .000 & & .000 & .000 & .000 \\
\hline \multirow{2}{*}{ Intention to Purchase } & $\begin{array}{l}\text { Pearson } \\
\text { Correlation }\end{array}$ & .849 & .839 & .947 & 1 & .729 & .860 \\
\hline & $\begin{array}{ll}\begin{array}{l}\text { Sig. } \\
\text { tailed) }\end{array} & \text { (2- } \\
\end{array}$ & .000 & .000 & .000 & & .000 & .000 \\
\hline \multirow{2}{*}{ Institution Assurance } & $\begin{array}{l}\text { Pearson } \\
\text { Correlation }\end{array}$ & .891 & $.782^{m}$ & $.787^{\prime \prime}$ & $.729^{*}$ & 1 & .806 \\
\hline & $\begin{array}{l}\text { Sig. } \\
\text { tailed) }\end{array}$ & .000 & .000 & .000 & .000 & & .000 \\
\hline \multirow[b]{2}{*}{ Website Quality } & $\begin{array}{l}\text { Pearson } \\
\text { Correlation }\end{array}$ & .894 & .899 & .897 & .860 & .806 & 1 \\
\hline & $\begin{array}{l}\text { Sig. } \\
\text { tailed) }\end{array}$ & .000 & .000 & .000 & .000 & .000 & .894 \\
\hline
\end{tabular}

\section{**. Correlation is significant at the $\mathbf{0 . 0 1}$ level (2-tailed).}

Table (5) presents results of multiple regression analysis prediction model using trust as the dependent variable. The regression results in table (5) were used to test H1, H1a, H1b, H1c, H1d, H2, H3, H3a, H3b, and $\mathrm{H} 4$. The effect of these variables explains $93.5 \%$ of the variance for consumer's trust in the airline websites. Hypotheses ( $\mathrm{H} 1, \mathrm{H} 1 \mathrm{a}, \mathrm{H} 1 \mathrm{~b}, \mathrm{H} 2, \mathrm{H} 3, \mathrm{H} 3 \mathrm{a}, \mathrm{H} 3 \mathrm{~b}$, and $\mathrm{H} 4)$ are fully supported. The results indicated that website quality $(\beta=.503 ; \mathrm{p}<0.01)$, information quality $(\beta=.191 ; \mathrm{p}<0.01)$, design quality $(\beta=-.444 ; p<0.01)$, company reputation $(\beta=.185 ; p<0.01)$, Institution assurance $(\beta=.486 ; p<0.01)$, perceived security protection $(\beta=.443 ; \mathrm{p}<0.01)$, perceived privacy protection $(\beta=.166 \mathrm{p}<0.01)$ and Word of mouth and recommendations $(\beta=.324 ; \mathrm{p}<0.01)$ have a significant effect on consumer trust in the airline websites. Hypotheses H1c and H1d are not supported. The results indicated that "perceived ease of use" $(\beta=.079 ; p>0.01)$, and "perceived usefulness" $(\beta=.195 ; p>0.01)$ would not affect consumer trust in the airline websites. Table 5 Regression results of study Hypotheses (H1 - H4) 


\begin{tabular}{|c|c|c|c|c|c|c|c|c|}
\hline \multirow{2}{*}{ Hypotheses } & \multirow{2}{*}{ Model } & \multicolumn{2}{|c|}{$\begin{array}{l}\text { Un-standardized } \\
\text { Coefficients }\end{array}$} & \multirow{2}{*}{$\begin{array}{c}\begin{array}{c}\text { Standardized } \\
\text { Coefficients }\end{array} \\
\text { Beta }\end{array}$} & \multirow{2}{*}{$\mathbf{t}$} & \multirow{2}{*}{ Sig. } & \multirow{2}{*}{$\begin{array}{l}\text { Adjusted } \\
\qquad \mathbf{R}^{2}\end{array}$} & \multirow{2}{*}{$\begin{array}{l}\text { supported vs. } \\
\text { rejected }\end{array}$} \\
\hline & & B & $\begin{array}{l}\text { Std. } \\
\text { Error }\end{array}$ & & & & & \\
\hline H1 & Website Quality & .518 & .047 & .503 & 11.080 & .000 & \multirow{10}{*}{.935} & $\begin{array}{c}\text { Supported } \\
\mathbf{P}<0.01\end{array}$ \\
\hline H1a & Information Quality & .186 & .049 & .191 & 3.832 & .000 & & $\begin{array}{c}\text { Supported } \\
\mathbf{P}<0.01\end{array}$ \\
\hline H1b & Design Quality & -.418 & .081 & -.444 & -5.187 & .000 & & $\begin{array}{c}\text { Supported } \\
\mathbf{P}<0.01\end{array}$ \\
\hline H1c & Perceived ease of use & .078 & .078 & .079 & .994 & .322 & & $\begin{array}{c}\text { Rejected } \\
\text { P>0.01 }\end{array}$ \\
\hline H1d & Perceived usefulness & .209 & .127 & .195 & 1.642 & .103 & & $\begin{array}{c}\text { Rejected } \\
\text { P>0.01 }\end{array}$ \\
\hline H2 & $\begin{array}{l}\text { Company } \\
\text { Reputation }\end{array}$ & .172 & .052 & .185 & 3.314 & .001 & & $\begin{array}{c}\text { Supported } \\
\mathbf{P}<0.01 \\
\end{array}$ \\
\hline H3 & $\begin{array}{l}\text { Institution } \\
\text { Assurance }\end{array}$ & .423 & .039 & .486 & 10.708 & .000 & & $\begin{array}{c}\text { Supported } \\
\mathbf{P}<0.01 \\
\end{array}$ \\
\hline H3a & $\begin{array}{l}\text { Perceived Security } \\
\text { Protection }\end{array}$ & .372 & .078 & .443 & 4.751 & .000 & & $\begin{array}{c}\text { Supported } \\
\mathbf{P}<0.01\end{array}$ \\
\hline H3b & $\begin{array}{c}\text { Perceived Privacy } \\
\text { Protection }\end{array}$ & .124 & .021 & .166 & 5.881 & .000 & & $\begin{array}{c}\text { Supported } \\
\mathbf{P}<0.01\end{array}$ \\
\hline H4 & $\begin{array}{c}\text { WOM and } \\
\text { Recommendations }\end{array}$ & .282 & .045 & .324 & 6.323 & .000 & & $\begin{array}{c}\text { Supported } \\
\mathbf{P}<0.01 \\
\end{array}$ \\
\hline
\end{tabular}

\section{a. Dependent Variable: Trust}

In testing Hypothesis 5 (H5) regression analysis was performed, with consumer trust as independent variable and purchase intentions as dependent variable. Table (6) illustrates the regression results used to test H5. Hypothesis 5 (H5) is fully supported. Consumer's trust in airline websites has a significant and positive influence on intentions to purchase $(\beta=.849 \mathrm{p}<0.01)$. The effect of consumer trust explains $72.1 \%$ of the variance for intentions to purchase from airline websites. Table (5) and table (6) summarize the results of the hypotheses testing, and Figure (2) presents these results.

\section{Table 6 Regression results of (H5)}

\begin{tabular}{|c|c|c|c|c|c|c|c|c|}
\hline Hypotheses & Model & \multicolumn{2}{|c|}{$\begin{array}{c}\text { Un-standardized } \\
\text { Coefficients } \\
\end{array}$} & $\begin{array}{c}\text { Standardized } \\
\text { Coefficients } \\
\text { Beta }\end{array}$ & $\mathbf{t}$ & Sig. & $\mathbf{R}^{2}$ & $\begin{array}{c}\text { supported vs. } \\
\text { rejected }\end{array}$ \\
\hline H5 & trust & .913 & .044 & .849 & 20.612 & .000 & .721 & $\begin{array}{c}\text { Supported } \\
\text { P<0.01 }\end{array}$ \\
\hline
\end{tabular}

b. Dependent Variable: Intention to purchase

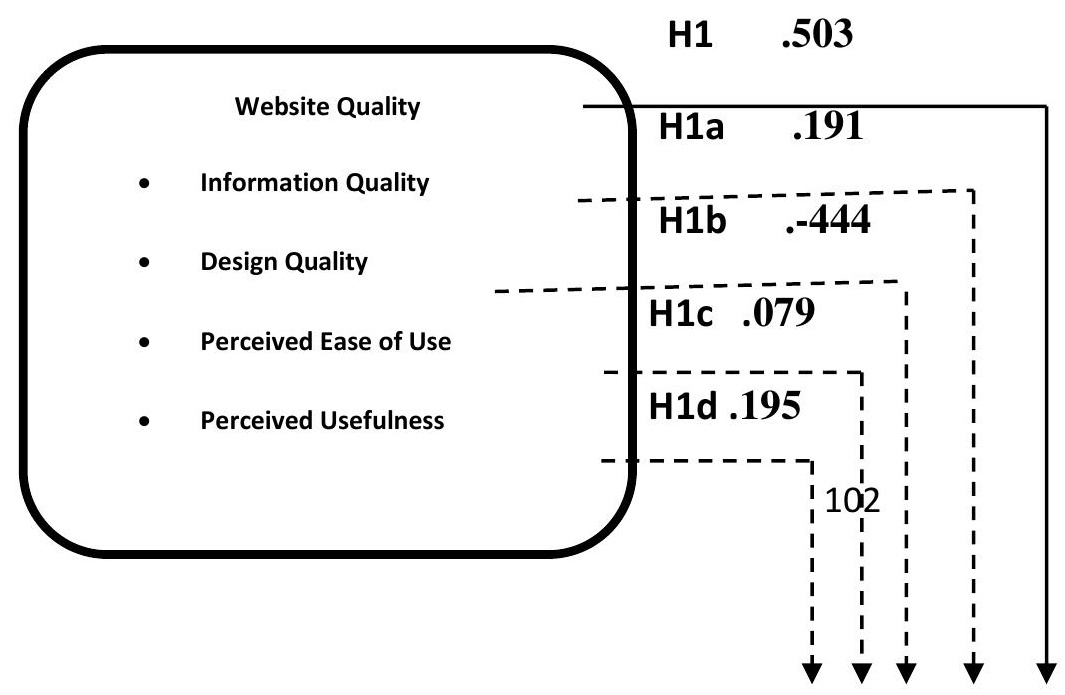




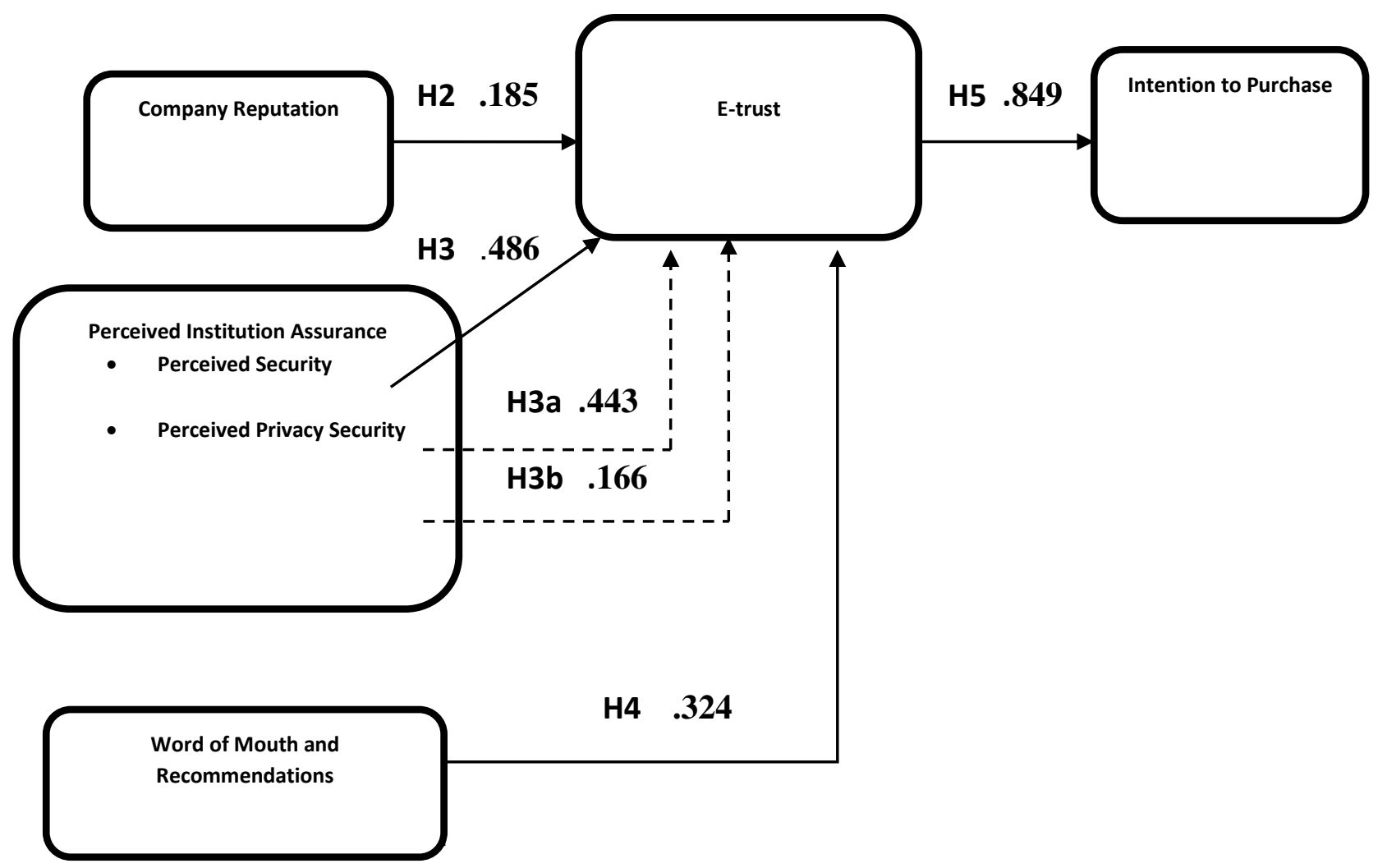

Figure 2: Results of the research model.

\section{Conclusion and Recommendations}

Trust has an important role in creating, building and developing a long-term relationship between the consumers and airlines, especially in the field of electronic transactions. The research model of this study proposes the key factors that influence consumer trust in airline websites. The model was tested using data collected from 166 respondents. Four factors, website quality and two of its dimensions (information quality and design quality), company reputation, perceived institution assurance and its dimensions (perceived security protection and perceived privacy protection) and word of mouth and recommendations were of a positive and significant effect on the consumer trust in airline websites. Whereas perceived ease of use and perceived usefulness have no effect on the consumer trust. The findings indicated that website quality is a strong predictor of the consumer trust in airline websites. Also information quality and design quality have a strong positive effect on consumer trust. The quality of information has a significant effect on consumer trust. Whenever the website provides complete, honest and up-to-date information, consumer trust in the site increases. A well designed airline website in terms of providing photos, graphics, possibility of language change, search bar and so on all have a positive influence on the consumer trust. These results are consistent with some of previous studies by (Corritore et al. 2005; Flavian and Guinalýu , 2006; Liao et al., 2006; Kim et al., 2008; Hsiao et al., 2010; Rahimnia and Hassanzadeh, 2013; Filieri et al., 2015). The results show that company reputation has a significant and positive effect on the consumer trust in airline websites. Company reputation represents the cornerstone in building consumer trust in airline websites, which means that good company reputation will increase and support the overall trust. This result is consistent with previous studies by (Chen, 2006; Kim et al., 2008; Tams, 2009; Hsiao et al., 2010; Agag and El-Masry, 2016). Another important finding of this study is that perceived institution assurance with its two dimensions (perceived security protection and perceived privacy protection) has a 
positive effect on the consumer trust and represents a strong predictor of consumer trust in airline websites. These results support the early findings (McKnight et al., 1998; Flavian and Guinalýu, 2006; Kim et al., 2008; Hsiao et al., 2010; Ponte et al., 2015). Security and privacy protection represents a critical issue in e-commerce and online transactions. When consumers feel that their personal information could be used without their permission, they will not trust in the airline company as well as its transactions. Also consumer will trust in airline website when he/she feels that this website is a safe environment based on a secure payment system. The findings of the study indicated that the word of mouth and recommendations has a positive effect on the consumer trust in airline websites. Positive WOM and recommendations by friends and relatives play a vital role in the formation and increase of the consumer trust. This result is consistent with studies by (Alam and Yasin, 2010). Finally, findings of the study showed that the consumer trust in airline websites is a strong predictor of intention to purchase. Consumer trust plays a critical role in making a purchase decision at online transactions. Several previous studies have confirmed the relationship between trust and the intention to purchase like (Sam and Tahir, 2009; Hsiao et al, 2010; Bigne, 2010; Kim et al., 2009, 2011; Escobar-Rodríguez and Carvajal-Trujillo, 2014; Ponte et al., 2015; Agag and El-Masry, 2016). The findings of the study reveal significant implications to help managers and marketers to know the factors that build and form trust in airline websites. Website quality plays a critical role in building consumer trust in airline websites in terms of information quality (e.g. reliable and up-to-date information), website design quality (e.g. photos, graphics, colors ...etc).

Therefore, procedures could be taken by managers to give website quality and its dimensions sufficient attention. The findings of the study presented the important role played by the company's reputation in increasing customer trust. Company reputation is essential for its survival in the marketplace. Managers and marketers should increase company reputation and its website through various strategies of marketing. Another important recommendation for airline managers to build consumer trust is to increase security and privacy considerations in their websites. For instance, airline website should provide a secure epayment environment that protects the electronic transactions of customers. Furthermore, airline websites must guarantee absolute protection of personal information. Airline website managers should also pay attention to the value and importance of word of mouth and recommendations, which plays an important and influential role in increasing consumer trust in airline website.

\section{References}

Agag, Gomaa M. and El-Masry, Ahmed A. (2016). Why do consumers trust online travel consumer trust toward online travel? Journal of Travel Research: 1-23.

Aiken, K. D., and Bousch, D. M. (2006). Trust-marks, objective-source ratings, and implied investments in advertising: Investigating online trust and the context specific nature of internet signals. Journal of the Academy of Marketing Science 34: 308-323.

Akehurst, G. (2009). User generated content: The use of blogs for tourism organizations and tourism consumers. Service Business 3(1): 51-61.

Alam, S. and Yasin, M. (2010). What factors influence online brand trust: evidence from online tickets buyers in Malaysia. Journal of Theoretical and Applied Electronic Commerce Research, 5(3):78-89.

Ba, S. and Pavlou, P.A. (2002). Evidence of the effect of trust building technology in electronic markets: Price premiums and buyer behavior. MIS Quarterly 26(3): 243-268.

Bahmanziari, T., Odom, M. D. and Ugrin, J.C. (2009). An experimental evaluation of the effects of internal and external e-assurance on initial trust formation in B2C E-commerce. International Journal of Accounting Information Systems 10(3): 152-170.

Barney, J.B. and Hansen, M.H. (1994). Trustworthiness as a source of competitive advantage. Strategic Management Journal 15: 175-190.

Bart, Y., Shankar, V., Sultan, F., and Urban, G. L. (2005). Are the drivers and role of online trust the same for all web sites and consumers? A large-scale exploratory empirical study. Journal of Marketing 69: 133-152.

Belanger, F., Hiller, J. S. and Smith, W .J. (2002). Trustworthiness in electronic commerce: The role of privacy, security, and site attributes. Journal of Strategic Information Systems 11 (December): 245-70. 
Bigne, E., Sanz, S., Ruiz, C., and Aldas, J. (2010). Why some internet users don't buy air tickets online. Information and Communication Technologies in Tourism 6: 209-221.

Borenstein, N.S. (1996). Perils and pitfalls of practical Cyb. Communications of the ACM 39 (6): 37-44. Chang, H.H and Chen, S.W. (2008). The impact of online store environment cues on purchase intention. Online Information Review 32 (6): 818-41.

Chellappa, R. K., and Pavlou, P. A. (2002). Perceived information security, financial liability and consumer trust in electronic commerce transactions. Logistics Information Management 15(5/6): 358368.

Chen, C. (2006). Identifying significant factors influencing consumer trust in an online travel site. Information Technology and Tourism 8(3/4): 197-214.

Chen, C. (2007). Passenger use intentions for electronic tickets on international flights. Journal of Air Transport Management 13(2): 110-115.

Chiu, L., C.P and Tang, L. (2005). Gender differs: assessing a model of online purchase intent ions in eretail service. International Journal of Service Industry Management 16(5): 416-435.

Chiu, C. M., Huang, H. Y., and Hui, Y. C. (2010). Antecedents of trust in online auctions. Electronic Commerce Research and Applications 9(2): 148-159.

Christou, E., Avdimiotis, P. Kassianidis, P. and Sigala, M. (2004). Examining the factors influencing the adoption of web-based ticketing: Etix and its adopters. In Information and communication technologies in Tourism In A.J. Frew (Ed.) Viena: Austria.

Corritore, C.L., Kracher, B. and Wiedenbeck, S. (2003). On-line trust: Concepts, evolving themes, a model. International. Journal of Human-Computer Studies 58:737-758

Corritore, C.L., Marble, R.P., Wiedenbeck, S., Kracher, B. and Chandran, A. (2005). Measuring online trust of websites: Credibility, perceived ease of use, and risk. AMCIS 2005 Proceedings, Paper, No. 370.

Coulter, K. and Coulter, R. (2002).Determinants of trust in a service provider: the moderating role of length of relationship. Journal of Services Marketing 16(1): 35-50.

Cunningham, L.F., Gerlach, J.H., Harper, M. and Young, C.E. (2005). Perceived risk and the consumer buying process: Internet airline reservations. International Journal of Service Industry Management 16(4): 357-372.

Cyr, D. (2008). Modeling web site design across cultures: Relationships to trust, satisfaction, and eloyalty. Journal of Management Information Systems 24(4): 47-72.

Cyr, D., Head, M. Larios, H. and Pan, B. (2009). Exploring human images in website design: A MultiMethod Approach. MIS Quarterly 33(3): 539-566.

Davis, F. D. (1989). Perceived usefulness, perceived ease of use, and user acceptance of information technology. MIS Quarterly 13(3): 319-340.

Dehbashi S. and Nahavandi N. (2007). Factors affecting on Iranian passengers' acceptance towards electronic ticketing provided by airlines. IADIS International Conference e-Society.

Detlor, B., Sproule, S., Gupta, C. (2003). Pre-purchase online information seeking: Search versus browse, Journal of Electronic Commerce Research 4 (2) :72-84.

Dong-Her, S., Hsiu- Sen, C., Chun-Yuan, C. and Lin, B. (2004).Internet security: Malicious E-mails detection and protection. Industrial Management \& Data Systems 104 (7):613-23.

Doney, P.M. and Cannon, J.P (1997). An examination of the nature of trust in buyer-seller relationships. Journal of Marketing 61 (April): 35-51.

Elliot, S., and Fowell, S. (2000). Expectations versus reality: A snapshot of consumer experiences with Internet retailing. International Journal of Information Management 20 (5): 323-336.

Eid, M. (2011). Determinants of e-commerce customer satisfaction, trust, and loyalty in Saudi Arabia. Journal of Electronic Commerce Research 12 (1):78-93.

Escobar-Rodíguez, T., and Carvajal-Trujillo, E. (2014). Online purchasing tickets for low cost carriers: An application of the unified theory of acceptance and use of technology (UTAUT) model. Tourism Management 43(August): 70-88. 
Filieri, R., Alguezaui , S. and McLeay, F. (2015). Why do travelers trust Trip Advisor? Antecedents of trust towards consumer-generated media and its influence on recommendation adoption and word of mouth. Tourism Management 51: 174-185.

Flavian, C. and Guinalýu, M. (2006). Consumer trust, perceived security and privacy policy: Three basic elements of loyalty to a web site. Industrial Management and Data Systems 106(5):601-620.

Flavián, C., Guinalýu , M., and Gurrea, R. (2006).The role played by perceived usability, satisfaction and consumer trust on website loyalty. Information Management 43(1): 1-14.

Forgas, S., Palau, R., Sánchez, J. and García, R. (2012).Online drivers and offline influences related to loyalty to airline websites. Journal of Air Transport 18(1):43-46.

Franzak, F., Pitta, D., and Fritsche, S. (2001). Online relationships and the consumer's right to privacy. Journal of Consumer Marketing 18: 631-641.

Fung, R.K.K. and Lee, M.K.O. (1999). EC-trust (trust in electronic commerce): Exploring the antecedent factors. In: Haseman, W.D., Nazareth, D.L. (Eds.), Proceedings of the Fifth Americas Conference on Information Systems, August 13-15, pp. 517-519.

Ganesan, S. (1994). Determinants of long-term orientation in buyer-seller relationships. Journal of Marketing 58: 1-19.

Gefen, D.; Karahanna, E. and Straub, D. (2003). Trust and TAM in Online Shopping: An Integrated Model, MIS Quarterly,vol. 27,No.1, pp. 51-90.

George, J.F. (2004). The theory of planned behavior and internet purchasing. Internet Research 14(3): 198-212.

Gil, M., Young, D. and Won, T., (2006). Impact of e-business on air travel markets: Distribution of airline tickets in Korea. Journal of Air Transport Management 12: 253-260.

Goodwin, C. (1991). Privacy: Recognition of a consumer right. Journal of Public Policy Marketing 10(1):149-166.

Goutam, C., Prashant, S. and Warren, D.L. (2005). Understanding corporate B2B websites effectiveness from North American and European perspective. Journal of Industrial Marketing Management 34 (10): 420-429.

Grace Lin, T. R., and Chia, C. S. (2009). Factors influencing satisfaction and loyalty in online shopping: An integrated model. Online Information Review 33 (3): 458-475.

Grazioli, S. and Jarvenpaa, S. (2000). Perils of Internet fraud: An empirical investigation of deception and trust with experienced Internet consumers. IEEE Transactions on Systems, Man, and Cybernetics 30 (4): 395-410.

Guo, Y. and Salvendy, G. (2009). The factor structure of content preparation for e-business websites: results of a survey of 428 industrial employees in the people's Republic of China. Journal of Behavior and Information Technology 28 (1):73-86.

Hassanein, K. and Head, M. (2007). Manipulating perceived social presence through the web interface and its impact on attitude towards online shopping. International Journal of Human-Computer Studies 65:689-708.

Harison E. and Boonstra, A. (2008). Reaching new altitudes in e-commerce: Assessing the performance of airlines websites. Journal of Air Transport Management 14(2): 92-98.

Hernandez, B, Jmenez, J. and Martın, M. J. (2009). Key website factors in e-business strategy. International Journal of Information Management 29 (5): 362-371.

Hoffman, D.L. and Novak, T.P. (1996).Marketing in hypermedia computer-mediated environments: Conceptual foundations. Journal of Marketing 60 (July): 50-68

Hoffman, D.L., Novak, T.P .and Peralta, M. (1999). Building consumer trust online. Communications of the ACM 42 (4): 80-85.

Ho, C. and Lee, Y. (2007).The development of an e-travel service quality scale. Tourism Management 28(6): 1434-1449.

Hsiao, K., Lin, J., Wang, X., Lu, H. and Yu, H. (2010).Antecedents and consequences of trust in online product recommendations. An empirical study in social shopping. Online information Review 34(6):935953. 
$\mathrm{Hu}, \mathrm{X}$., Lin, Z., and Zhang, H. (2001). Myth or reality: Effect of trust-promoting seals in electronic markets. Presented at WITS 2001. New Orleans, LA, USA.

$\mathrm{Hu}, \mathrm{X} ., \mathrm{Wu}, \mathrm{G} ., \mathrm{Wu}, \mathrm{Y}$. and Zhang, H. (2010). The effects of web assurance seals on consumers' initial trust in an online vendor: A functional perspective. Decision Support Systems 48(2): 407-418.

Hwang, P. and Burgers, W. (1997). Properties of trust: An analytical view. Organizational Behavior and Human Decision Processes 69 (1): 67-73.

Jarvenpaa, S., Tractinsky, J., Saarinen, L., and Vitale, M. (1999). Consumer trust in an Internet store: A cross-cultural validation. Journal of Computer-Mediated Communication 5(2): 59-88.

Jarvenpaa, S.L., Tractinsky, J., Vitale, M., (2000). Consumer trust in an Internet store. Information Technology and Management 1 (1/2): 45-71.

Karimov , F. Brengman, M. and Hove, L. (2011). The effect of website design dimensions on initial trust: A synthesis of the empirical literature. Journal of Electronic Commerce Research 12(4):272-301.

Koehn, D. (2003). The nature of and conditions for online trust. Journal of Business Ethics 43: 3-19.

Kim, S. and Lee, H. (2004). Organizational factors affecting knowledge sharing capabilities in EGovernment: An Empirical study. Proceedings of the 2004 Annual National Conference on Digital Government Research, Seattle, WA.

Kim, S. and Stoel, L. (2004). Apparel retailers: Website quality dimensions and satisfaction. Journal of Retailing and Consumer Services 11 (3): 109-117.

Kim, H.W., Xu, Y. and Koh, J. (2004). A comparison of online trust building factors between potential customers and repeat customers. Journal of the Association for Information Systems 5(10): 392-420.

Kim, D.J., Ferrin, D.L. and Rao, H.R. (2008). A trust-based consumer decision-making model in electronic commerce: The role of trust, perceived risk, and their antecedents. Decision Support Systems 44(2): 544-564.

Kim, D. J., Song, Y. I., Braynoy, S. B., and Rao, H. R. (2005). A multidimensional trust formation model in B-to-C e-commerce: A conceptual framework and content analyses of academia/practitioner perspectives. Decision Support Systems 40: 143-165.

Kim H. B., Kim, T. and Shin, S. W. (2009) Modeling roles of subjective norms and e-trust in customers' acceptance of airline B2C ecommerce web sites. Tourism Management 30(2): 266-277.

Kim, M., Chung, N and Lee, C. (2011).The effect of perceived trust on electronic commerce: Shopping online for tourism products and services in South Korea. Tourism Management 32: 256-265.

Kim, H.W., Xu, Y., and Gupta, S. (2012). Which is more important in Internet shopping, perceived price or trust? Electronic Commerce Research and Applications 11(3): 241-252.

Kimery, K. M., and Mc Cord, M. (2002). Third-party assurance: mapping the road to trust in e-retailing. Journal of Information Technology Theory and Application 4(2): 63-82.

Kiong, T., Gharleghim, B., Yin-Fah, B. and Kei, L. (2014). Electronic Ticketing in Airline Industries among Malaysians: the Determinants. International Journal of Business and Social Science 5(9):168174.

Kolsaker, A. and Payne, C. (2002). Engendering trust in E-commerce: A study of gender-based concerns. Marketing Intelligence and Planning 20(4):206-214.

Komiak, S.X. and Benbasat, I. (2004). Understanding customer trust in agent-mediated electronic commerce, web-mediated electronic commerce, and traditional commerce. Information Technology and Management 5(1): 181-207.

Koufaris, M., and Hampton-Sosa, W. (2002). Customer trust online. Examining the experience with the website.CIS Working Paper Series (\#CIS-2002-05) New York: Zicklin School of Business, Baruch College.

Lauer, T. W., and Deng, X. (2007). Building online trust through privacy practices. International Journal of Information Security 6: 323-331.

Law, R. and Leung, R. (2000). A study of airlines' online reservation services on the internet. Journal of Travel Research 39(2).

Lee, C. and Huh, J. (2010). Website trust evaluation as cognitive information processing and the moderating role of situational involvement and e-commerce knowledge. International Journal of Internet Marketing and Advertising 6(2): 168-198. 
Lee, G. and Lin, H. (2005). Customer perceptions of e-service quality in online shopping. International Journal of Retail and Distribution Management 33(2):161-176.

Lee, J., Love, C. and Han, T. (2008). Trade show website: An examination of critical websites, quality factors and content items. Journal of Convention and Event Tourism 9 (1): 35-59.

Liao, C., Palvia, P., and Lin, H. N. (2006). The roles of habit and website quality in ecommerce. International Journal of Information Management 26: 469-483.

Lin, H. F. (2007). The impact of website quality dimensions on customer satisfaction in the B2C ecommerce context. Total Quality Management, 18(4): 363-78.

Lin, H.C. (2008). The study of the antecedents of customer loyalty on internet banking in Indonesia. Master Thesis. UFC, Indonesia.

Lin, T. (2010). Examining e-travel sites: an empirical study in Taiwan. Online Information Review 34(2): 205-228.

Ling, K., Daud, D., Piew, T., Keoy, K. and and Hassan, P. (2011). Perceived risk, perceived technology, online trust for the online purchase intention in Malaysia, International Journal of Business and Management 6(6):167-182.

Liu, C., and Arnett, K.P. (2000). Exploring the factors associated with website success in the context of electronic commerce. Information and Management 38: 23-33.

Lohse, G. L., and Spiller, P. (1998). Electronic shopping. Communications of the ACM 41(7): 81-87.

Lubbe, B. (2007).The effect of Internet apprehension and website satisfaction on air travelers' adoption of an airline's website. Journal of Air Transport Management 13(2): 75-80.

Luna-Nevarez, C. and Hyman, M.R. (2012). Common practices in destination website design. Journal of Destination Marketing and Management 1:94-106.

Manganari, E.E., Siomkos, G.J., and Vrechopoulos, A.P. (2009). Store atmosphere in web retailing. European Journal of Marketing 43(9/10): 1140-1153.

Mayer, R.C., Davis, J.H. and Schoorman, F.D. (1995). An integrative model of organizational trust. Academy of Management Review 20(3): 709-734.

Mazhar, F., Jam, F. and Anwar, F. (2012).Consumer trust in e-commerce: A study of consumer perceptions in Pakistan. African Journal of Business Management 6 (7): 2516-2528.

Mc Cole, P. (2002). The role of trust for electronic commerce in services. International Journal of Contemporary Hospitality Management 14(2): 81-87.

McKnight, D.H., Cummings, L.L., and Chervany, N.L. (1998). Initial trust formation in new organizational relationships. Academy of Management Review 23: 473-490.

McKnight, D. H., Choudhury, V., and Kacmar, C. (2002). Developing and validating trust measures for Ecommerce: An integrative typology. Information Systems Research 13(3): 397-416.

McKnight D.H., Kacmar, C.J and Choudhury, V. (2004). Shifting factors and the ineffectiveness of third party assurance seals: A two-stage model of initial trust in a web business. Electronic Markets 14(3): 252-266.

Moorman C., Deshpande, C.R. and Zaltman, G., (1993). Factors affecting trust in market research relationships. Journal of Marketing 57 (1): 81-101.

Morrison, A.M., Jing, S., O'Leary, J.T. and Cai, L.A. (2001). Predicting usage of the Internet for travel bookings: An exploratory study. Information Technology and Tourism 4(1):15-30.

Neilsen, J. (1998). Introduction to web design. In Proceedings of the Conference on CHI 98 Summary. Los Angeles, CA, USA.

Nusair, K. and Kandampully, J. (2008). The antecedents of customer satisfaction with online t ravel services: a conceptual model. European Business Review 20(1): 4-19.

O'Connor, P. and Frew, A. (2002). The future of hotel electronic distribution: Expert and industry perspectives. Cornell Hotel and Restaurant Administration Quarterly 43(3): 33-45.

Osman, S., Chan, Y.F.B., and Choo, B.H. (2010). Undergraduate and online purchasing behavior. Canadian Center of Science and Education 6(10): 133-146.

Öztüren, A. (2013). Effects of Electronic Trust on Purchase Intentions in Online Social Review Networks: The Case of Tripadvisor.com. Life Science Journal 10(2): 2002-2010. 
Palmer, J. W. (2002). Website usability, design and performance metrics, Information Systems Research 13 (2):157-167.

Palvia, P. (2009). The role of trust in e-commerce relational exchange: A unified model. Information and Management 46 (2): 213-220.

Parasuraman, A., Zeithaml, V.A. and Berry, L.L., (1985). A conceptual model of service quality and its implications for future research. The Journal of Marketing 49(4): 41-50.

Parasuraman, A., Zeithaml, V.A. and Malhotra, A. (2005). E-S-QUAL: A multiple-item scale for assessing electronic service quality. Journal of Service Research 7(3): 213-233.

Park, C. and Kim, Y. (2003). Identifying key factors affecting consumer purchase behavior in an online shopping context. International Journal of Retail \& Distribution Management 31(1):16-29.

Pavlou, P. A. (2003). Consumer acceptance of electronic commerce: integrating trust and risk with the technology acceptance model. International Journal of Electronic Commerce 7(3): 69-103.

Perea, T., Dellaert, B.C., and De Ruyter, K. (2004). What drives consumers to shop online? A literature review. International Journal of Service Management 15(1): 102-121.

Ponte, E., Trujillo, E. and Rodríguez, T. (2015). Influence of trust and perceived value on the intention to purchase travel online: Integrating the effects of assurance on trust antecedents. Tourism Management 47: 286-302.

Rahimnia, F. and Hassanzadeh, J. (2013). The impact of website content dimension and e-trust on emarketing effectiveness: The case of Iranian commercial saffron corporations. Information \& Management 50:240-247.

Ray, S., Ow, T., and Kim, S. S. (2011). Security assurance: How online service providers can influence security control perceptions and gain trust. Decision Sciences 42(2): 391-412.

Robbins, S.S. and Stylianou, A.C. (2003). Global corporate websites: An empirical investigation of content and design. Information and Management 40 (5): 205-222.

Ruiz, C., Sanz, S. and Aldás, J., (2009). Drivers and barriers to online ticket purchasing. Journal of Air Transport Management 15: 294-298.

RuelNovabos, C., Matias, A. and Mena, M. (2015). How good is this destination website: A user-centered evaluation of provincial tourism websites? Procedia Manufacturing 3: 3478 - 3485.

Sam, M. and Tahir, M. (2009). Website Quality and Consumer Online Purchase Intention of Air Ticket. International Journal of Basic \& Applied Sciences 9(10):4-9.

Shankar, V., Urban, G. L. and Sultan, F. (2002).Online trust: A stakeholder perspective, concepts, implications and future directions. Journal of Strategic Information Systems 11(December): 325-44.

Shapiro, S. P. (1987). The social control of impersonal trust. American Journal of Sociology 93: 623658.

Shchiglik C. and Barness, S. J. (2004). Evaluating website quality in the airline industry. Journal of Computer Information System 44(3): 17-25.

Shon, Z. Y., Chen, F. Y., and Chang, Y. H. (2003). Airline e-commerce: The revolution in ticketing channels. Journal of Air Transport Management 9(3): 285-295.

Sitkin, Sim, B. and Roth, N. (1993). Explaining the Limited Effectiveness of Legalistic 'Remedies' for Trust/Distrust. Organization Science 4 (August): 367-92.

Smeltzer, L. (1997). The meaning and origin of trust in buyer-seller relationships. International Journal of Purchasing and Materials Management 33(1): 40-48.

Su, Q., Li, Z., Song, Yong-Tao and Chen, T. (2008). Conceptualizing consumers' perception of ecommerce quality. International Journal of Retail and Distribution Management 36(5)

Sultan, F., Urban, G.L., Shankar, V. and Bart, I. (2002). Determinants and consequences of trust in ebusiness. Working Paper, Sloan School of Management, MIT, Cambridge, MA 02142.

Surjadjaja, H., Ghosh, S., and Antony, J. (2003). Determining and assessing the determinants of e-service operations. Managing Service quality 13(1): 39-53.

Tan, F.B., Tung, L. L and Xu, Y. (2009). Study of web-designers' criteria for effective business-toconsumer (B2C) websites using the repertory grid technique. Journal of Electronic Commerce Research 10(3): 155-177. 
Taylor, M. J., and England, D. (2006). Internet marketing: Website navigational design issues. Marketing Intelligence and Planning 24(1): 77-85.

Tsai, H. T., Huang, L., and Lin, C. G. (2005). Emerging e-commerce development model for Taiwanese travel agencies. Information and Management 26(5): 787-796.

Urban, G.L., Sultan, F. and Qualls, W. (2000).Placing trust at the center of your internet strategy. Sloan Management Review 42 (1): 39-48.

Verhagen, T., and Van Dolen, W. (2009). Online purchase intentions: A multi-channel store image perspective. Information and Management 46: 77-82.

Wang, Y.D. and Emurian, H.H (2005). An overview of online trust: Concepts, elements, and implications. Computers in Human Behavior 21(1): 105-125.

Wang, J.W. and Wu, H.L. (2011). Understanding repeat purchase intentions and uncertainty in the context of online shopping. In Proceedings Pacific Asia Conference on Information Systems (PACIS) at AIS Electronic Library (AISeL), Paper 207.

Wei, J. and Ozok, A., (2005). Development of a web-based mobile airline ticketing model with usability features. Industrial Management Data System 105 (9) 1261-1277.

Winnie, P. (2014). The Effects of Website Quality on Customer e-Loyalty: The Mediating Effect of Trustworthiness. International Journal of Academic Research in Business and Social Sciences 4(3):19-41.

Xiaoying, G. Kwek, C. L. and Min, L. (2012). Evaluating factors influencing consumer satisfaction towards online shopping in China. Asian Social Science 8 (13): 40-50.

Yoon, S.J. (2002). The antecedents and consequences of trust in online purchase decisions. Journal of Interactive Marketing 16 (2): 47-63.

Yoo, B. and Donthu, N. (2001) Developing a scale to measure the perceived quality of an Internet shopping site (SITEQUAL). Quarterly Journal of Electronic Commerce 2(1): 31-46.

Yu, S.F. (2008). Price perception of online airline ticket shoppers. Journal of Air Transport Management 14 (2): 66-69.

Zeithaml, V.A., Parasuraman, A. and Malhotra, A., (2000). A conceptual framework for understanding eservice quality: Implications for future research and managerial practice. Marketing Science Institute.

Zeithaml, V.A., Parasuraman, A., and Malhotra, A. (2002). Service quality delivery through web sites: A critical review of extant knowledge. Journal of the Academic of Marketing Science 30(4): 358-371.

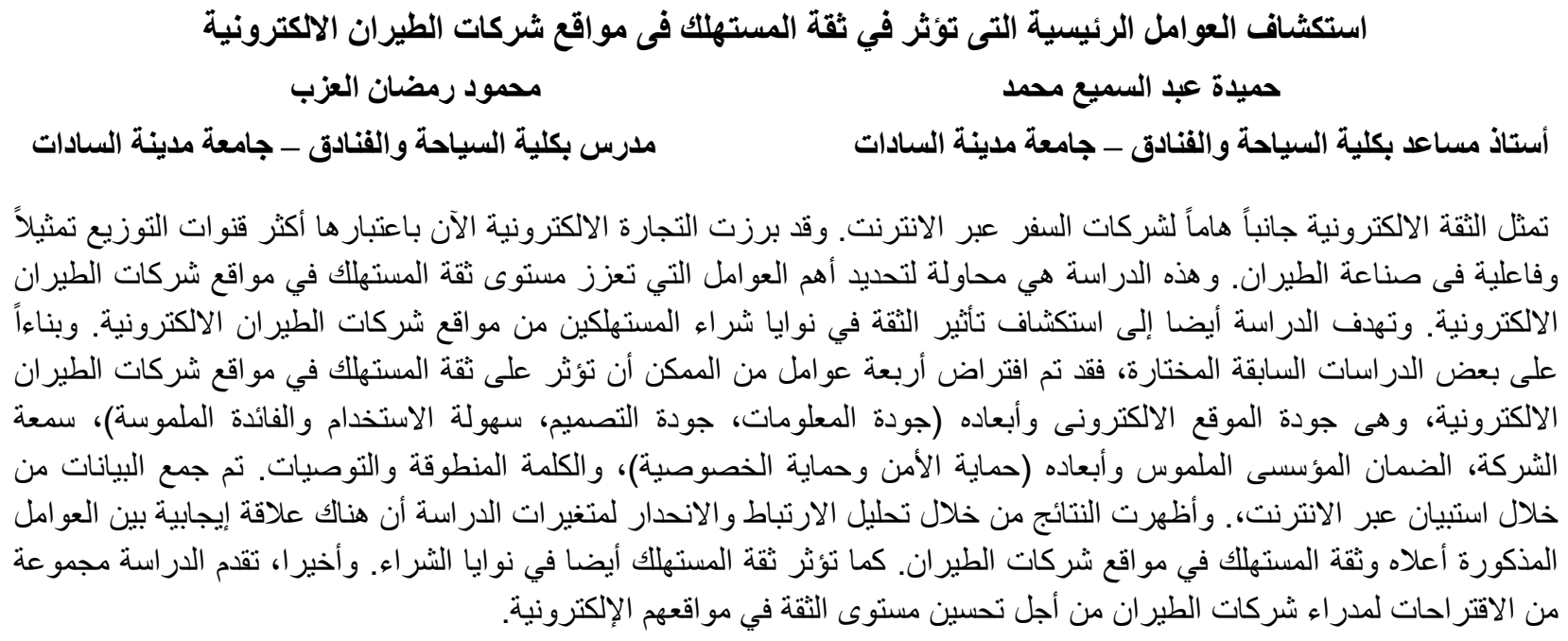

